\title{
Hiring and firing gets more complex
}

TWENTY, even ten years ago the personnel management side of industry or indeed of any employer was a relatively minor affair. Employers hired when they needed new people and fired when the need had gone away or if they felt their employees were incompetent. The system was undoubtedly harsh, particularly on manual workers who could be dumped almost at a moment's notice, and few would deny that the recent trends in many countries towards more job security have been humane and have reduced drastically the opportunities for exploitation. But few would also deny that these trends, enshrined in employment legislation, have not only placed far greater demands on personnel management but have also tied employers' hands to a degree that can restrict ability to survive in a rapidly changing world.

It is certain that when legislation is being framed the last people who are likely to be in parliaments' minds are university research staff, yet it is amongst this community that some of the least desirable backwash from the legislation can be found. There are two reasons for this-that science moves quickly and may cruelly strand its practitioners in a world they cannot cope with, and that modest ability, even coupled with a strong drive, is often insufficient in a small group in which every member must play a major role. You can stop employers exploiting by means of legislation, but science itself, by its rapid and unpredictable methods of evolution, in a sense exploits its own practitioners in a way that cannot be legislated against. So what happens when research institutions, the presumed guardians of the spirit of science come up against employment legislation? In recent months a clear conflict arose in the United States when a nationwide raising of the age to which people could work if they wished produced cries of horror from universities aghast at the thought of five more years' employment from professors whose involvement with scholarship had waned, to say the least.

In the UK, where the elderly form nothing like as strong a lobby, the pressure, if anything, is to lower the retirement age, but that does not mean that there are not other employment pitfalls. Take, for instance, the hiring of postdoctoral workers, research assistants and technical staff on short-term contracts. For many years this has been a well-tried procedure for giving younger scientists their first taste of self-propelled research as a testing ground for suitability for more permanent employment. In recent years with a decline in the number of permanent posts coming on to the market and with a reduced willingness amongst scientists to move around, short-term posts on research grants have taken on a greater significance and have often had to be the holding pattern in which excellent young scientists have to circle for years and years before they can alight on a permanent position. But with recently enacted legislation, particularly the Redundancy Payments Act and the Employment Protection Act, things are not so easy as they used to be.

Case history on fixed-term contracts is still being established in the courts, but the pattern that seems to be emerging is that a contract between employer and employee for a fixed period is to be regarded as just that-neither side is at liberty to terminate the contract by giving notice except in the case of a fundamental breach such as wilful misconduct by the employee. In theory an employee who has done, say, two and a half years of a three year contract and then is offered a post elsewhere is unable to take up this new post until the contract has expired, although in practice blind eyes are being turned.

Nor is it entirely simple to end the contract even when its nominal period has expired. These days expiry of a fixed-term contract is regarded as dismissal, and it is open to an employee to attempt to claim for unfair dismissal or to seek redundancy payments. Employers are, however, at liberty to ask potential employees to sign a clause in their contracts waiving their rights to such claims.

Those administrators who are trying to establish satisfactory new contracts describe the scene as a legal minefield. Scientists who are in the position of employing people on short-term contracts are divided as to how much the new legislation affects research. Opinions vary from the expression of the view that it could 'make it very difficult to undertake research on three-year grants' through to the assertion that it will simply 'make sure that we take care to hire the right people in the first place'. There is little doubt, however, that another small restraint has been imposed on freedom to do research. 